\title{
Geneza asystencji wojskowej w II Rzeczypospolitej
}

\begin{abstract}
The article presents the issue of the genesis of military assistance in the Second Polish Republic.

In interwar Poland, this term was understood as providing aid by the armed forces for the benefit of civil authorities, primarily in connection with ensuring public safety, or in the event of natural disasters. The text analyzes Polish and foreign experiences with the use of the army for the indicated purposes, as well as characterizes the regulations of foreign countries established before 1918 in this field. In the period from January to April 1919, basic regulations concerning the discussed issues were issued.

Mianem asystencji wojskowej w Polsce międzywojennej określano wsparcie udzielane władzom cywilnym przez siły zbrojne w sytuacji konieczności zapewnienia bezpieczeństwa publicznego, w celach zapobiegawczych i ratunkowych podczas klęsk żywiołowych oraz w innych przewidzianych $\mathrm{w}$ prawie przypadkach. ${ }^{1}$ Pomocy udzielano przy tym $-\mathrm{z}$ pewnymi wyjątkami - jedynie na wezwanie uprawnionego przedstawiciela władz cywilnych, kiedy nie były one w stanie własnymi siłami zapewnić odpowiedniego zabezpieczenia porządku publicznego lub ratunku poszkodowanym. Oddziały i pododdziały wojskowe przeznaczone do tego typu zadań nazywano asystencyjnymi. Dotychczasowe badania pokazują, że Wojsko Polskie (WP) udzielało wsparcia organom administracji publicznej w ramach: ochrony konstytucyjnego porządku państwa, prowadzenia działań
\end{abstract}

\footnotetext{
Encyklopedia wojskowa, red. Otton Laskowski, t. 1 (Warszawa: Wyd. Towarzystwa Wiedzy Wojskowej i Wojskowego Instytutu Naukowo-Wydawniczego, 1931), 149.
} 
przeciwdywersyjnych, utrzymywania lub przywracania zbiorowo naruszonego porządku publicznego, bezpośredniego udziału w przedsięwzięciach Policji Państwowej lub innych podmiotów bezpieczeństwa wewnętrznego, ochrony porządku w przypadku wyborów powszechnych, zorganizowanego przejazdu poborowych lub osób zwolnionych $z$ wojska do rezerwy, jak również $\mathrm{w}$ razie wystąpienia klęsk żywiołowych (elementarnych). Oprócz powyższego, pomocy udzielano także sądom i prokuratorom. Wypracowany w II Rzeczypospolitej system udzielania asystencji w praktyce obejmował wszystkie jednostki wojskowe, a sposoby i procedury prowadzenia tego typu przedsięwzięć były szczegółowo opisane $\mathrm{w}$ wewnętrznych przepisach wojskowych i częściowo także w aktach normatywnych. ${ }^{2}$

Spośród wszelkich uregulowań dotyczących podejmowanej problematyki kluczowe znaczenie miało wydane w kwietniu 1919 r. rozporządzenie Rady Ministrów o sposobie użycia wojska dla zabezpieczenia porząadku publicznego. ${ }^{3}$ Ten dosyć obszerny oraz szczegółowo zredagowany akt prawny obowiązywał z niewielkimi zmianami do końca istnienia II RP i stanowił podstawę merytoryczną wielu wojskowych regulaminów oraz instrukcji. ${ }^{4}$ W rozporządzeniu tym enumeratywnie wyliczono sytuacje, w których możliwa była pomoc sił zbrojnych dla władz cywilnych, a także wprost wyrażono zasadę ostateczności wzywania wojska (tj. jedynie po stwierdzeniu braku dalszych możliwości zapobiegania zagrożeniu zwykłymi środkami) oraz działania na podstawie żądania przedstawicieli władz publicznych. ${ }^{5}$ Przewidywano przy tym cztery przypadki użycia broni przez żołnierzy: pierwszy - przy rozruchach lub „manifestacjach o charakterze rozruchów” na wyraźne i umotywowane żądanie uprawnionych przedstawicieli władzy cywilnej: „kiedy ich poprzednie wezwania do przywrócenia stanu prawnego pozostały bez skutku, a dowódca oddziału tego rodzaju interwencję wojska uzna za konieczną"; drugi - „gdy oddział wojska czynnie lub zbrojnie zostanie napadnięty”; trzeci - „gdy tłum przeszkadza wojsku w posuwaniu

2 O tej problematyce zob. także Piotr Hac, „Asystencja wojskowa w II RP. Cz. I Przepisy regulujące i zasady udzielania,” Kwartalnik Bellona 99, nr 3 (2017): 116-134; Hac, „Asystencja wojskowa w II Rzeczypospolitej. Cz. II Aspekty praktyczne," Kwartalnik Bellona 99, nr 4 (2017): 52-70.

3 Rozporządzenie Rady Ministrów z dnia 18 kwietnia 1919 r. o sposobie użycia wojska dla zabezpieczenia porządku publicznego (Dziennik Praw Państwa Polskiego z 1919, nr 35, poz. 276).

4 Przede wszystkim części VIII Regulaminu służby wewnętrznej z 1925 r., na której oparto system stosowania asystencji wojskowej w II Rzeczypospolitej. Centralne Archiwum Wojskowe Wojskowego Biura Historycznego, Instrukcje i regulaminy przedwojenne, sygn. 399.

Na temat tego aktu normatywnego zob. Hac, „Asystencja wojskowa,” 1:119-121. Omawia go także Krzysztof Gąsiorek w pracy Wojskowe wsparcie władz cywilnych i społeczeństwa, red. i oprac. Gąsiorek i Waldemar Kitler (Warszawa: Akademia Obrony Narodowej, 2005), $70-72$. 
się lub pełnieniu akcji, do której wojsko zostało powołane” i czwarty - „w razie zbrodni i gwałtów, popełnianych w obecności wojska”. ${ }^{6}$ Nakazywano, aby przy rozpędzaniu tłumu oszczędzać „w miarę możności kobiet i dzieci, starców i osób, nie biorących udziału w rozruchach”, a „natarcie bagnetem lub salwę poprzedzić winien potrójny sygnał trąbkąa." Trzeba przyznać, że zastosowany w tej regulacji zalecany opis sposobów prowadzenia działań asystencyjnych nie był standardowy jak na akt normatywny, a zawierając w sobie wiele zagadnień taktycznych, przypominał instrukcję wojskową.

Pomimo wagi omawianych zagadnień problematyka asystencji wojskowej wciąż nie doczekała się odrębnej monografii i występuje w publikacjach jedynie jako jeden $\mathrm{z}$ elementów przedstawianych treści. ${ }^{8} \mathrm{~W}$ ostatnich latach doszło wprawdzie w tej materii do poszerzenia stanu wiedzy, głównie za sprawą opracowań dotyczących przypadków użycia wojska w międzywojennej Polsce do zapewnienia bezpieczeństwa publicznego oraz ukazujących funkcjonowanie konkretnych garnizonów wojskowych lub formacji. ${ }^{9}$ Niemniej w dalszym ciągu wiele kwestii wymaga wyjaśnienia. Z pewnością jedną z nich jest poznanie genezy asystencji wojskowej w II RP, w tym rodowodu przyjętych w tym zakresie rozwiązań oraz świadomości polskich wojskowych w momencie odtwarzania państwowości co do ewentualności wykorzystania żołnierzy do tego typu zadań. Podjęcie próby odniesienia się do tych zagadnień jest celem niniejszego artykułu. Przyjęto, że niezbędne będzie przedstawienie wybranych

6 Art. 23, 24 i 28 rozporządzenia Rady Ministrów o sposobie użycia wojska dla zabezpieczenia porządku publicznego.

7 W projekcie części IV Regulaminu służby wewnętrznej z 1936 r. przed użyciem broni palnej nakazywano trzykrotne głośne ostrzeżenie ustne: „Rozejść się! Wojsko strzela!”, poprzedzone odegraniem na trąbce sygnału „Szturm”, zob. Hac, „Asystencja wojskowa,” 1:128.

8 Odniosłem się do tego w wymienionych publikacjach na temat asystencji wojskowej mojego autorstwa. Tam także przedstawiłem dostępną do roku 2016 literaturę przedmiotu.

9 Mowa tu o: Adam Adrian Ostanek, Wydarzenia 1930 roku w Małopolsce Wschodniej a bezpieczeństwo II Rzeczypospolitej (Warszawa: Wyd. Adam Ostanek, 2017); Artur Ochał, Na litewskiej rubieży. Brygada KOP „Grodno” (1929-1939) (Warszawa: Instytut Pamięci Narodowej, 2017); Maciej Franz, Mariusz Kardas i Ostanek, Wojsko Polskie a sytuacja wewnętrzna Małopolski Wschodniej. Działalność Rejonów bezpieczeństwa 5., 11. i 12. Dywizji Piechoty w latach 1924-1925 (Warszawa: Stara Szuflada, 2018); Rzeczpospolita niedoskonała. Dokumenty do historii buntu społecznego w latach 1930-1935, wstęp i oprac. Piotr Cichoracki et al. (Łomianki-Kraków: Wyd. LTW, 2019); Przemysław Wywiał, Garnizon Wojska Polskiego w Krakowie w latach 1918-1939 (Kraków: Wyd. Księgarnia Akademicka, 2019). Warto jeszcze wspomnieć o artykułach poświęconych problematyce asystencji wojskowej: Tadeusz Banaszek, „Służba asystencyjna Wojska Polskiego w II Rzeczypospolitej - przyczynki źródłowe," Świętokrzyskie Studia Archiwalno-Historyczne 5, (2016): 272-274; Cichoracki i Janusz Mierzwa, „Akcja asystencyjna jednostek Wojska Polskiego w zachodniej części województwa lwowskiego (czerwiec-lipiec 1933 r.)," Przegląd Historyczno-Wojskowy (PHW) 18 (69), nr 4 (262) (2017): 139-151 oraz Robert Litwiński, „O bezpieczeństwo wewnętrzne odrodzonej Rzeczypospolitej (1917-1922)," PHW 19 (70), nr 1/2 (263/264) (2018): 218-244. 
doświadczeń historycznych z użycia wojska do zapewnienia bezpieczeństwa wewnętrznego, jak również zastanowienie się nad możliwościami skorzystania z tej wiedzy przez formujące się Wojsko Polskie. Istotne znaczenie mógł tutaj spełniać austriacki (austro-węgierski) system asystencji wojskowej, dlatego poświęcono mu szczególną uwagę. Ramy czasowe poniższego tekstu obejmują także pierwsze miesiące funkcjonowania państwa polskiego po odzyskaniu niepodległości, w czasie których uzyskano własne doświadczenia praktyczne w omawianym zakresie. Za datę końcową wywodu uznano kwiecień 1919 r., kiedy to wydano wspomniane powyżej rozporządzenie Rady Ministrów.

\section{Doświadczenia historyczne w korzystaniu z pomocy wojska do zapewnienia bezpieczeństwa wewnętrznego}

Biorąc pod uwagę potrzebę zachowania bezpieczeństwa wewnętrznego w państwie, wojsko od czasów najdawniejszych było z reguły pierwszą (i często jedyną) siłą przymusu, która była w dyspozycji władcy. Zauważalna była łatwość, $\mathrm{z}$ jaką można było - w realiach starożytności i wczesnego średniowiecza - wykorzystać żołnierzy do wykonywania działań z zakresu utrzymania bezpieczeństwa i porządku publicznego, choćby z uwagi na fakt użytkowania uzbrojenia (np. broni białej i tarcz) oraz prowadzenia dosyć prostych czynności (ochrona i obrona obiektów, patrolowanie, kontrolowanie osób i środków transportu, zatrzymywanie osób). Z kolei przeciwdziałanie ewentualnym zagrożeniom dla ustroju państwa i jego władz (zamachy stanu, rebelie, powstania) sprowadzało się $\mathrm{w}$ istocie do walki $\mathrm{z}$ podobnie zorganizowanym i uzbrojonym przeciwnikiem.

Wiek XVIII przyniósł rozwój cywilizacyjny Europy, wraz ze stopniową zmianą uwarunkowań socjalnych i zwiększeniem roli rosnących ośrodków miejskich. Przy coraz większej liczbie ludności skala wystąpień społecznych wzrastała. W Wielkiej Brytanii już w 1714 r. dla „zapobiegania powstawaniu gwałtownych i buntowniczych zgromadzeń oraz dla szybszego i efektywniejszego karania buntowników" wydano stosowne regulacje rangi ustawowej (The Riot Act), z których w przyszłości będą korzystać także brytyjscy żołnierze. ${ }^{10}$ Należy zauważyć, że w Rzeczypospolitej w artykule XI konstytucji z 3 maja 1791 r. stwierdzono, że „wojsko winno narodowi strzeżenie granic i spokojności powszechnej [...] użytym być wojsko narodowe na ogólną kraju obronę, na strzeżenie fortec i granic lub na pomoc prawu, gdyby kto egzekucyi jego nie był posłusznym". ${ }^{11}$

10 „The Riot Act,” gutenberg.org, dostęp lipiec 23, 2019, http://www.gutenberg.org/files/8142/8142-h/8142-h.htm.

11 Cyt. za: Konstytucja 3 maja 1791 na podstawie tekstu ustawy rządowej z archiwum Sejmu Czteroletniego przechowywanego w Archiwum Głównym Akt Dawnych w Warszawie, oprac. 
Wiek XIX można uznać za okres powszechnego tworzenia w Europie państwowych formacji policyjnych, rozumianych jako uzbrojone, umundurowane i wyodrębnione organizacje administracyjne, wypełniające zadania z pomocą zawodowego personelu, chroniące życie, zdrowie i mienie ludzi oraz zapewniające bezpieczeństwo i porządek publiczny, a ponadto pełniące określone funkcje $\mathrm{w}$ ściganiu przestępstw i wykroczeń. ${ }^{12}$ Związane to było z procesami powstawania państw narodowych, nowymi formami organizacji społeczeństw, postępującą rewolucją przemysłową, rozwojem miast, jak również z pojawiającą się tendencją do wzmacniania ówczesnych służb porządkowych przez władze. Niektóre kraje wykształciły formacje militarne o kompetencjach policyjnych - jak np. Włochy (karabinierzy), Francja, Turcja, Rumunia (żandarmeria), Hiszpania (gwardia cywilna) czy Portugalia (gwardia narodowa) - które działały obok policji. ${ }^{13} \mathrm{~W}$ państwach, na które ze względu na obejmowanie władztwa nad ziemiami polskimi warto zwrócić szczególną uwagę, tj. Rosję, Prusy (Niemcy) i Austrię (Austro-Węgry), organizacja systemu organów zapewniających bezpieczeństwo i porządek publiczny w XIX w. bazowała na połączeniu funkcjonowania żandarmerii oraz policji administracyjnych (ogólnoporządkowych). ${ }^{14}$

Wraz z liczebnym, organizacyjnym i kompetencyjnym rozwojem podległych sobie cywilnych formacji policyjnych władze publiczne uzyskiwały nowe możliwości egzekwowania za ich pomocą wydawanych przez siebie dla ludności poleceń - co mogło skutkować zmniejszeniem potrzeb w zakresie korzystania z pomocy jednostek wojskowych. W pewnych sytuacjach wciąż jednak opcję taką wykorzystywano. Wobec faktycznego bra$\mathrm{ku}$ zdolności formacji policyjnych do radzenia sobie z tłumem używano wówczas do pomocy żołnierzy, których jedyne możliwości oddziaływania

i wstęp Anna Grześkowiak-Krwawicz (Warszawa: Archiwum Główne Akt Dawnych, 2018), 79.

12 Piotr Majer, Bezpieczeństwo wewnętrzne Polski w rozwoju dziejowym od X wieku do końca Polski Ludowej (Szczytno: Wyd. WSPol, 2012), 90. Oczywiście formacje policyjne istniały w niektórych państwach już w XVIII w., a nawet wcześniej, jednak z reguły podlegały władzom miejskim. W Polsce pod koniec istnienia I Rzeczpospolitej powołano Departament Policji przy Radzie Nieustającej (w 1775 r.), a Konstytucją 3 maja - Komisję Policji. Organy te wypełniały także inne zadania, dzisiaj niekojarzone $\mathrm{z}$ policyjnymi. $\mathrm{W}$ czasie powstania kościuszkowskiego władze insurekcji powołały w Warszawie korpus Policji, mający m.in. zapobiegać rozruchom w mieście, szerzej w: ibid., 115-117.

13 Ibid., 90-91. Karina Paulina Marczuk, Trzecia opcja: gwardie narodowe w wybranych państwach basenu Morza Śródziemnego (Toruń-Łysomice: Europejskie Centrum Edukacyjne, 2009), 23.

14 Szerzej w: Majer, Bezpieczeństwo, 100-101; Marczuk, Trzecia, 39, 43. W zakresie rozwiązań dotyczących systemu bezpieczeństwa wewnętrznego w Rosji w XIX i na początku XX w. warto zapoznać się z: Krzysztof R. Kowalczyński, Łódź 1905. Kulisy rewolucji (Łódź: Wyd. Księży Młyn, 2017), 16-20; Jan Kozłowski, „Straż ziemska w Królestwie Polskim w latach 1867-1875," Przeglad Historyczny 91, nr 4 (2000): 519-534. 
na zgromadzonych polegały na stosowaniu broni. Przykładowo w sierpniu 1819 r. w Manchesterze w Wielkiej Brytanii, po przedwczesnym pisemnym wezwaniu o pomoc wojskową przez przedstawicieli władz publicznych, doszło do szarży dwóch pułków kawalerii na bezbronny wielotysięczny tłum (tzw. Petrloo Massacre), czego skutkiem była śmierć kilkunastu osób oraz zranienie kilkuset kolejnych. ${ }^{15} \mathrm{~W}$ Stanach Zjednoczonych Ameryki żołnierzy armii regularnej po raz pierwszy zaangażowano do tłumienia strajków w roku 1834, a uznaje się, że w okresie 1870-1900 korzystano z takiej pomocy 150 razy. ${ }^{16}$ Natomiast w 1896 r. w brytyjskim porcie Newlyn, starcia pomiędzy rywalizującymi grupami rybaków przerosły możliwości policji, a sytuację ostatecznie uspokojono, wykorzystując 300 żołnierzy piechoty oraz dwa okręty. ${ }^{17} \mathrm{~W} 1911 \mathrm{r}$. francuskie władze rządowe musiały zaangażować aż 40 tys. wojskowych, aby zapanować nad zamieszkami, które wybuchły pomiędzy plantatorami winogron a producentami szampana $\mathrm{w}$ jednej z prowincji kraju. ${ }^{18}$

Należy zaznaczyć, że tak jak w wiekach poprzednich, tak również w omawianym okresie wojsko brało udział w zwalczaniu zbrojnych prób zmiany ustroju państw (np. komuna paryska) oraz dążeń niepodległościowych lub separatystycznych (np. powstanie styczniowe na ziemiach polskich i ziemiach zabranych). W tego typu przypadkach prowadzono $\mathrm{z}$ reguły regularne walki z uzbrojonym na modłę wojskową przeciwnikiem lub zwalczano partyzantkę, do czego nie nadawała się żadna formacja policyjna. ${ }^{19}$

Podczas rewolucji 1905 r. w Rosji oraz Królestwie Polskim wojsko wielokrotnie było używane do przywracania naruszonego zbiorowo porządku publicznego. Przede wszystkim wynikało to ze skali wystąpień robotniczych i chłopskich, przerastających możliwości opanowania sytuacji przez formacje policyjne. W wielu przypadkach partyjne grupy bojowe atakowały oraz rozbrajały policjantów lub żandarmów (jak np. podczas powstania

15 Zob. materiał internetowy z oficjalnej strony poświęconej zdarzeniu: peterloomassacre.org, dostęp sierpień 22, 2019, http://www.peterloomassacre.org /history.html.

16 Byron Farwell, The Encyclopedia of Nineteenth-Century Land Warfare: an illustrated world view (New York-London: W.W. Norton \& Company, 2001), 199.

17 „Newlyn Riots 1896,” west-penwith.org.uk, dostęp sierpień 23, 2019, https://west-penwith.org.uk/riot.htm.

18 Szczegóły na stronie internetowej dotyczącej zdarzenia: maisons-champagne.com, dostęp sierpień 24, 2019, https://maisons-champagne.com/en/encyclopedias/champagne-guest-bo$\mathrm{ok} /$ before-sparkling-champagne/xxe-centuries/article/revolution-in-the-vineyards.

19 Podczas powstania styczniowego władze rosyjskie nie były zadowolone $\mathrm{z}$ działania różnych formacji policyjnych w Królestwie Polskim, m.in. z uwagi na porzucanie służby przez funkcjonariuszy narodowości polskiej, jak i ogólną niekompetencję. Negatywna ocena była podstawą reorganizacji tych formacji, Kozłowski, „Straż ziemska,” 519 i n. 
w Moskwie w grudniu 1905 r.), często decydując się nawet na otwarte walki z pododdziałami wojskowymi. ${ }^{20}$ Po wprowadzeniu w czerwcu 1905 r. stanu wojennego dla miasta Łodzi oraz powiatu łódzkiego, dotychczasowe cyrkuły (obwody) policyjne przekształcono na wojskowe i komendę nad nimi objęli oficerowie wojska. ${ }^{21}$

Poważnym wyzwaniem dla zapewnienia bezpieczeństwa publicznego na terenie Królestwa Polskiego były masowe wystąpienia robotników rolnych, które miały miejsce w latach 1905-1907. Zazwyczaj organizowali się oni w kilkusetosobowe grupy, wędrujące od folwarku do folwarku i wymuszające przy użyciu przemocy (lub groźby) różnego rodzaju korzyści. ${ }^{22}$ Początkowo siły policji okazały się zbyt szczupłe, aby zagwarantować bezpieczeństwo właścicieli ziemskich, co wywoływało wśród nich niepokój, a często nawet panikę. Wojsko brało udział w obławach na grupy tych robotników rolnych bądź bezpośrednio reagowało na zakłócenia prawa. ${ }^{23}$

W zakresie klęsk żywiołowych czy elementarnych lub wydarzeń nadzwyczajnych warte odnotowania jest wykorzystywanie wojska do pomocy osobom poszkodowanym. W sierpniu $1850 \mathrm{r}$. w Warszawie, w związku z potężnym pożarem budynków mieszkalnych na kilku sąsiadujących ze sobą ulicach, żołnierze zapewniali bezpieczeństwo, jak również podstawowe wyżywienie ewakuowanym rodzinom..$^{24}$ Natomiast podczas powodzi w maju 1877 r. w Krakowie akcja władz miejskich, podejmowana wspólnie z siłami wojskowymi, polegała na usuwaniu zatorów lodowych, ostrzeganiu ludności, jej przesiedlaniu oraz niesieniu pomocy potrzebującym. ${ }^{25}$

\section{Doświadczenia i regulacje austriackie (austro-węgierskie) dotyczące asystencji wojskowej do 1918 r.}

Pierwsze dekrety austriackie co do udzielania pomocy przez wojsko dla władz cywilnych zostały wydane w listopadzie $1785 \mathrm{r}$. oraz w styczniu

\footnotetext{
20 Kowalczyński, Łódź 1905, 30, 100. Co do powstania w Moskwie: Zbigniew Ryniewicz, Bitwy świata: leksykon (Warszawa: Wiedza Powszechna, 1995), 391.

${ }^{21}$ Kowalczyński, Łódź 1905, 106-107.

22 Szerzej o tej problematyce w: Jan Molenda, „Walka o poprawę warunków materialnego bytu robotników rolnych poprzez przemoc grupową i rokowania w rewolucji 1905-1907 roku w Królestwie Polskim," w Rewolucja 1905-1907 w Królestwie Polskim i w Rosji, red. Marek Przeniosło i Stanisław Wiech (Kielce: Wyd. Akademii Świętokrzyskiej, 2005), 59-72.

23 Ibid., 64.

24 Piotr Wierzbicki, „Warszawski czerwony kur,” Skarpa Warszawska, lipiec 2019, nr 7, 30.

25 Elżbieta Adamczyk, „Władze samorządnego Krakowa wobec klęsk naturalnych nawiedzających miasto w dobie autonomii galicyjskiej," w Od powietrza, głodu, ognia i wojny... Klęski elementarne na przestrzeni wieków, red. Tomasz Głowiński i Elżbieta Kościk (Wrocław: Wyd. GAJT, 2013), 183.
} 
1786 r. Wyjaśniały one znaczenie „asystencji wojskowej” (Militärassistenz) rozumianej jako udzielanie pomocy w sytuacji buntów (gwałtownego oporu) całych społeczności lub przynajmniej większej liczby osób, działających wbrew (wydanym na podstawie obowiązujących przepisów) poleceniom władz publicznych, oraz węższe pojęcie „egzekucji wojskowej” (Militärexekution) - traktowanej jako środek przymusu do ściągania wprowadzonych podatków lub podobnej rangi obciążeń. ${ }^{26}$ Oba te zwroty będą się początkowo ze sobą zazębiać. W latach późniejszych potwierdzano możliwość prowadzenia asystencji wojskowej w zakresie ściągalności podatków, zaznaczając, że pomoc wojskowa podlega organom, które ją skierowały do działań, a nie wierzycielom. ${ }^{27}$

W wydanym w 1832 r. i mającym tłumaczyć chłopom pańszczyźnianym ich obowiązki Katechizmie poddanych galicyjskich o prawach $i$ powinnościach podstawę do zastosowania oraz zasady prowadzenia asystencji wojskowej opisano następująco: „poddani wzbraniający się odbywać powinności gruntowych, mogą być do nich zmuszeni przez wojskową assystencję [...] jest [to] pewna liczba żołnierzy, zwierzchności gruntowej przez urząd cyrkułowy, do wymuszenia powinności zaległych dodana [...] powinna nieposłusznych poddanych do pańszczyzny wyganiać, do dworu sprowadzać, słowem pachołków dworskich we wszystkim wspierać, a zatem exekucja wojskowa przykra jest kieszeni, assystencja zaś kieszeni i osobie samej poddanego [...] Assystencji należy się to samo co exekucji wojskowej, to jest: szeregowemu po sześć, kapralowi po dwanaście a feldweblowi po osiemnaście grajcaró $w^{28}$ dziennie; wszakże przy trwającym uporze poddanych, należność ta nigdy podwyższoną nie bywa, ale natomiast liczba wojska się pomnaża, tak że jedna wieś może dostać $20,30,40,100,200$ i więcej żołnierzy na przełamanie swojego uporu [...] zjeżdża urzędnik cyrkułowy na miejsce i przy pomocy wojska, krnąbrnych poddanych surowo na ciele kijami chłosta, dopóki ich do posłuszeństwa nie przyprowadzi [...] nie można się oprzeć assystencji wojskowej, bo ta koniecznie posłuszeństwo poddanych wymusić powinna; a gdy poddani gwałtem się opierają, wojsko może

\footnotetext{
26 Richard Georg Plaschka, Horst Haselsteiner i Arnold Suppan, Innere Front. Militärassistenz, Widerstand und Umsturz in der Donaumonarchie 1918, cz. 1, Zwischen streik und meuterei (München: R. Oldenbourg Verlag, 1974), 21. Jest to prawdopodobnie najbardziej wartościowa $\mathrm{z}$ dotychczas wydanych na rynku europejskim prac dotyczących wybranych aspektów asystencji wojskowej, szczegółowo omawiająca tego typu działania w Austro-Węgrzech w 1918 r., w tym na ziemiach polskich. Jej recenzja została opublikowana przez Jana Lewandowskiego w Przeglądzie Historycznym 68, nr 4 (1977): 785-789.
}

27 Zob. pkt 45 w: Prowincyonalny Zbior Praw Galicyi i Lodomeryi za rok 1828, wydanego za naywyższym rozkazem pod dozorem c.k. galicyjskiego krajowego Gubernium (Lwów: b.w., [1829]), 97.

28 Grajcar - srebrna moneta używana na terenie cesarstwa austriackiego. 
bagnetem nacierać, albo i ostro strzelać, przy czem wielu krnąbrnych swoje nieposłuszeństwo życiem opłaca". ${ }^{29}$

Począwszy od lat czterdziestych XIX w., asystencja wojskowa w Austrii z działań faktycznie wspierających czynności przymuszania do spłaty podatków i innych zobowiązań przekształciła się w instytucję nakierowaną na udzielanie pomocy organom władzy publicznej w celu zapewnienia zbiorowo naruszonego porządku publicznego. W rozporządzeniu z 8 października 1844 r. oraz w dekrecie z 19 października 1844 r. określono m.in. zasady użycia broni przez żołnierzy $\mathrm{w}$ trakcie prowadzenia asystencji, uznając, że wykorzystanie przymusu przez wojsko podczas wsparcia władz publicznych może mieć dwie podstawy: na żądanie uprawnionego urzędnika państwowego, po wyczerpaniu wszystkich innych środków przymusu, lub wobec bezpośredniego ataku na pododdział asystencyjny, nawet jeśli nie było takiego żądania. Do uprawnień dowódcy pododdziału udzielającego pomocy pozostawiono decyzję o sposobie użycia broni białej (bagnetów) lub palnej - zależnie od okoliczności zdarzenia. Uwypuklano także rolę „silnego przywództwa" oddziału asystencyjnego jako istotnego elementu skutecznych działań oraz odpowiedniego wyboru dowódcy i starannego określenia potrzebnej do wykonania zadania liczby żołnierzy. ${ }^{30}$ Dodatkowo w instrukcji wydanej 29 stycznia 1849 r. przez ministra spraw wewnętrznych podkreślono, że prowadzenie asystencji wojskowej powinno być ostatecznością, którą należy stosować jedynie w najważniejszych przypadkach i tylko wtedy, gdy wszystkie polubowne środki oddziaływania, napominania, ostrzegania oraz grożenia wobec osób łamiących prawo okazały się bezowocne. ${ }^{31}$ Zapewne uznając wagę oraz trudność prowadzenia czynności asystencyjnych, rozporządzeniem z 20 kwietnia 1854 r. przewidziano dla żołnierzy biorących udział w tego typu akcjach specjalne dodatki finansowe. ${ }^{32}$

W regulaminie Cesarsko-Królewskiej Armii z 9 sierpnia 1873 r. jeden rozdział poświęcono angażowaniu pododdziałów wojskowych do utrzymania bezpieczeństwa i porządku publicznego. Podzielony on został na części dotyczące: asystencji, zachowania żołnierzy przed wystąpieniem oraz podczas rozruchów, wykorzystania pododdziałów wobec tłumu, pełnienia służby wartowniczej oraz patrolowej. W kolejnym wydaniu regulaminu (lata 1886-1887) rozszerzono z kolei wymogi dotyczące meldowania

\footnotetext{
29 Katechizm poddanych galicyjskich o prawach i powinnościach ich względem Rzadu, Dworu i samych siebie przez Konstantego Leliwa Słotwińskiego (Lwów: b.w., 1832), 124-126. W cytacie poprawiono niektóre anachronizmy językowe i zrezygnowano $\mathrm{z}$ niepotrzebnych wielkich liter.

30 Plaschka, Haselsteiner i Suppan, Innere Front, 1:22-23.

$31 \quad$ Ibid., 1:23.

32 Ibid. Podobnego rodzaju dodatki dla żołnierzy stosowano później także w wojsku II Rzeczypospolitej.
} 
przełożonym o przypadkach oraz efektach prowadzenia czynności asystencyjnych. ${ }^{33}$

Niewątpliwie duże znaczenie dla omawianej problematyki miał wydany w 1908 r. projekt instrukcji dotyczącej wymagań i sposobu prowadzenia asystencji wojskowej, gdyż - pomimo przeznaczenia na czas pokoju - faktycznie obowiązywał on i był używany do upadku Austro-Węgier w 1918 r. W instrukcji tej określono, że do pomocy władzom publicznym w zapewnieniu im niezbędnej siły do egzekwowania wydawanych przez nie poleceń mogą być wzywane pododdziały sił zbrojnych - w szczególności w przypadku napotkania gwałtownego oporu bądź też do utrzymania lub przywrócenia bezpieczeństwa i porządku publicznego, jeżeli dostępne tym władzom środki nie byłyby wystarczające do osiągnięcia założonych celów. ${ }^{34}$

We wspomnianej instrukcji autorzy podjęli się również wyłuszczenia wskazówek taktycznych, jak również określenia przypadków użycia broni palnej przez żołnierzy. Przede wszystkim zwracano uwagę na wdrożenie działań mających na celu zapobieżenie ewentualnemu wybuchowi zamieszek i konieczności użycia siły w ogóle, w szczególności poprzez odpowiednie planowanie, zdecydowane działania oraz wprowadzanie do akcji silnych pododdziałów, których sama liczebność miała skłaniać oponentów do odstąpienia od wszczynania rozruchów. W przypadku podjęcia decyzji o użyciu siły nakazywano jej eskalowanie, począwszy od środków mniej dolegliwych (np. bagnety) do ostatecznych (broń palna). Sugerowano, aby w celu rozproszenia tłumu - gdy pozwalają na to okoliczności - przede wszystkim używać piechoty, która po bezskutecznym wezwaniu zgromadzonych do rozejścia się, oszczędzając nieuzbrojone kobiety, dzieci i starców, przystąpi do ataku na bagnety, poprzedzonego sygnałem „do szturmu!”. Jeżeli nie przyniosłoby to oczekiwanego efektu lub w przypadku, gdy pododdział asystencyjny zostałby ostrzelany bądź zmuszony do samoobrony, oczekiwano użycia broni palnej, zaznaczając jednak, że nie należy już wtedy stosować ślepych naboi lub strzelać $\mathrm{w}$ powietrze. $\mathrm{W}$ przypadku użycia broni należało dążyć do pełnego rozproszenia tłumu, bez podejmowania jakichkolwiek prób paktowania $\mathrm{z}$ demonstrantami. Jednocześnie $\mathrm{w}$ sytuacji napotkania buntowniczo nastawionego zgrupowania uzbrojonych osób lub stawiania przez nich silnego oporu istniała możliwość zastosowania wobec nich

\footnotetext{
33 Ibid., 1:24.

34 Ibid., 1:25. Oryginalny tytuł tej instrukcji brzmiał: Entwurf. Instruktion bezüglich Anforderung, Beistellung und Verwendung militärischer Assistenzen. Ten akt prawny opatrzony był wprawdzie mianem "projektu”, jednak miał moc obowiązującą zgodne z przyjętą w wielu siłach zbrojnych zasadą wydawania dokumentu o charakterze tymczasowej instrukcji, co do której nie wyklucza się wprowadzenia zmian po pewnym okresie jej faktycznego stosowania. Praktykę tę przejęło także Wojsko Polskie w II Rzeczypospolitej.
} 
"odpowiednich sił i środków”, co w praktyce stanowiło formalne zezwolenie na wykorzystanie broni o większej mocy oddziaływania (np. artylerii). ${ }^{35}$

$\mathrm{W}$ instrukcji sugerowano, aby kawalerii używać w pierwszych stadiach gromadzenia się tłumu, przede wszystkim do oczyszczania ulic oraz placów z osób gromadzących się - i to raczej bez stosowania siły. Podobnie jak w przypadku piechoty, wkroczenie do akcji kawalerii miało być poprzedzone dźwiękowym ostrzeżeniem. ${ }^{36}$

W instrukcji przewidziano trzy przypadki użycia broni:

- przy burzliwych i buntowniczych wystąpieniach społecznych, na wyraźne oraz uzasadnione żądanie kompetentnego przedstawiciela władzy publicznej, którego wcześniejsze wezwania do zachowania zgodnego z prawem nie zostały przyjęte, przy czym dowódca wojskowy musi być przekonany o zasadności takiego żądania;

- gdy pododdział wojskowy został zbrojnie zaatakowany lub osoby uzbrojone w broń bądź inne niebezpieczne przedmioty działają we wrogich intencjach przeciwko żołnierzom lub próbują odebrać im broń bądź blokują im możliwość wykonania zadania;

- w celu przywrócenia bezpieczeństwa i porządku publicznego lub w sytuacji wystąpienia aktów przemocy wobec osób, mienia lub obiektów użyteczności publicznej, po wcześniejszym wezwaniu przez dowódcę wojskowego do zachowania zgodnego z prawem, gdy żądanie to nie zostało spełnione. ${ }^{37}$

Twórcy instrukcji zauważali zapewne trudności i skomplikowany charakter działań asystencyjnych jako prowadzonych przeciwko obywatelom własnego państwa i podejmowanych w sytuacji wystąpienia znacznego wzburzenia społecznego, gdy trudno wymagać od tłumu racjonalnego

35 Ibid., 27-30.

36 Ibid., 30.

37 W oryginale: „a) bei Tumulten und aufrührerischen Bewegungen auf ausdrückliches und begründetes Verlagen des ermächtigter politischen Beamten (berufenen Organes) in jenen Fällen, in welchen dessen vorausgegangene Aufforderungen zur Herstellung des gesetzlichen Zustandes erfolglos geblieben sind, und auch der Kommandant der ihm beigegebenen Truppen von der Notwendigkeit eines solchen Einschreitens überzeugt ist; b) wenn eine Truppe tätlich insultiert oder gar mit Waffen angegriffen wird, desgleichen, wenn Leute mit Waffen oder sonstigen Gewaltwerkzeugen in feindseliger Absicht gegen die Truppen drängen und zu besorgen ist, daß hiedurch deren Aktionsfähigkeit verhindert oder übermäßig beengt werde; c) wenn bei einer zur Wiederherstellung der Ordnung und Sicherheit ausgerückten Truppe oder einem selbständigen Teile derselben ein politischer Beamter nicht anwesend ist, so hat bei Eintritt von Gewaltakten gegen die Sicherheit der Person, des Eigentums oder öffentlicher Einrichtungen der Kommandant dieser Truppe die Aufforderung zur Herstellung des gesetzlichen Zustandes zu erlassen und im Falle diese Aufforderung, nicht befolgt wird - selbst wenn die Truppe nicht behelligt würde - mit der Anwendung von Gewaltmaßregeln nach eigenem Ermessen einzuschreiten", tłumaczenie własne autora, cytat za: ibid., 29. 
postępowania. Posiadano jednak świadomość, że wkroczenie do akcji wojska powinno być ostatecznym sposobem przywrócenia porządku publicznego i w celu jego osiągnięcia działania żołnierzy muszą być zdecydowane. „Każdy dowódca działa ostrożnie, jednak strzeże się półśrodków” - jak to ostatecznie skwitowano. ${ }^{38}$

Oczywiście powyżej przedstawione przykłady unormowań austro-węgierskich, dotyczących udzielania przez wojsko pomocy dla władz cywilnych, nie były jedynymi obowiązującymi w tamtym czasie w Europie. Jako przykład można podać pruskie regulacje z 1837 r., dotyczące zasad i przypadków użycia broni przez żołnierzy, lub bawarskie z 1851 r. (Das Einschreiten der bewaffneten Macht zur Erhaltung der gesetzlichen Ordnung betreffend), odnoszące się do interwencji wojska w związku z utrzymaniem porządku prawnego. Warto $\mathrm{w}$ tym miejscu również wspomnieć o rozwiązaniach francuskich z 1883 r. (Reglement sur le service dans les places de guerre et les villes de garnison) bądź włoskich z $1886 \mathrm{r}$. (Truppa in servizio di Pubblica Sicurezza). ${ }^{39}$

Wszelkie austro-węgierskie doświadczenia w prowadzeniu czynności asystencyjnych uwypukliły się szczególnie w roku 1918, choć do przypadków jej prowadzenia w czasie wojny dochodziło w latach poprzednich. Ciężka sytuacja ekonomiczna oraz aprowizacyjna kraju, jak również zmęczenie działaniami wojennymi i wzrost nastrojów rewolucyjnych wywołały od stycznia tego roku masowe wystąpienia społeczne oraz strajki. ${ }^{40}$ Począwszy od 3 stycznia tr., z oddziałów rezerwowych piechoty zaczęto wystawiać pododdziały asystencyjne, generalnie $\mathrm{w}$ wielkości kompanii (Assistentzkompanie - często wsparte przez plutony karabinów maszynowych), rzadziej szwadronów kawalerii (Assistentschwadron) lub baterii artylerii, których zadaniem początkowo była ochrona zakładów przemysłowych przed dewastacją i sabotażem. ${ }^{41}$ Pogarszająca się sytuacja w kraju oraz narastający problem strajkowy spowodowały, że dla samych

38 W oryginale: „Jeder Kommandant hüte sich vor halben Maßregeln”, tłumaczenie własne autora, cytat za: ibid., 30-31.

39 Ibid., 26-27.

40 W styczniu 1918 r. w Austrii zaprzestało pracy ok. 700 tys. robotników, a na Węgrzech ok. 500 tys. Problem ten nie dotyczył zresztą tylko tego kraju. Pomimo trwania wojny i zmilitaryzowania większości zakładów produkcyjnych w ciągu całej I wojny światowej doszło do niespotykanej na dotychczasową skalę liczby strajków. Według szacunków, w latach 19151918 na Wyspach Brytyjskich doszło do 3227 wystąpień z udziałem 2,6 mln pracowników, a we Francji odpowiednio - 1608 i 520 tys. osób. Do strajków dochodziło wówczas także w krajach neutralnych, jak np. Szwajcarii, Holandii i Hiszpanii. Charakterystyczne dla tej wojny były manifestacje kobiet, szerzej w: Andrzej Chwalba, Samobójstwo Europy. Wielka wojna 1914-1918 (Kraków: Wyd. Literackie, 2014), passim.

41 Plaschka, Haselsteiner i Suppan, Innere Front, 1:59 i 78. Z uwagi na wielonarodowość armii zwracano przy tym uwagę, aby pododdziały złożone w większości z żołnierzy danej narodowości nie wykonywały czynności asystencyjnych w „swojej” części monarchii. 
Węgier zdecydowano się na zorganizowanie 60 kompanii asystencyjnych liczących średnio po 100 ludzi. 22 stycznia tr. w Wiedniu rozlokowano 14 tego typu kompanii, 1 szwadron i 11 plutonów ckm, przy czym siły te zostały podzielone na sześć grup bojowych. ${ }^{42}$ Ostatecznie z przebywających wówczas w głębi kraju oddziałów do 23 stycznia wystawiono ogółem 335 kompanii asystencyjnych oraz 13 baterii artylerii, co $\mathrm{z}$ różnymi pododdziałami wsparcia dawało łącznie ponad 40 tys. żołnierzy zaangażowanych tylko do tego typu działań. ${ }^{43}$

$\mathrm{W}$ wielu przypadkach pododdziały asystencyjne brały udział w tłumieniu buntów wojskowych oraz cywilnych rozruchów. Przykładowo w trakcie zamieszek, które wybuchły w Krakowie w dniach 11-13 lutego 1918 r., szef miejscowej policji zwrócił się o pomoc w postaci 500 żołnierzy piechoty oraz 20 kawalerzystów, których dowództwo garnizonu niezwłocznie przydzieliło. $\mathrm{Z}$ uwagi na wzrost napięcia 12 lutego tr. wyznaczone siły wzmocniono o kolejnych 500 ludzi. ${ }^{44}$

W drugiej połowie 1918 r., z uwagi na wzrastające potrzeby frontu zdecydowano się na tworzenie $\mathrm{z}$ formacji zapasowych 70 specjalnych batalionów asystencyjnych (Assistenzbaone), złożonych jedynie $\mathrm{z}$ wybranych i pewnych żołnierzy, co miało zapewnić sprawne wykonywanie zadań. W październiku $1918 \mathrm{r}$. władze ponownie sprowadziły z frontu wiele oddziałów, rozmieszczając je w miejscach spodziewanych wystąpień antypaństwowych, jednak wówczas już nawet $\mathrm{w}$ samych pododdziałach asystencyjnych wystąpiły kłopoty $\mathrm{z}$ utrzymaniem dyscypliny. ${ }^{45}$

\section{Początki asystencji wojskowej w II Rzeczypospolitej}

Można przyjąć, że tematyka zasad prowadzenia asystencji wojskowej nie była kompletnie obca dla wojskowych narodowości polskiej, szczególnie dla oficerów pełniących służbę $w$ armii austro-węgierskiej. Wydaje się prawdopodobne, że w trakcie szkoleń zapoznawali się oni z treścią różnych regulacji na ten temat (np. z projektem instrukcji z 1908 r.). ${ }^{46} \mathrm{Nie}$ moż-

42 Ibid., 1:79-81.

43 Ibid., 1:83.

44 Ibid., 1:97-102; Marian Zgórniak, 1914-1918. Studia i szkice z dziejów I wojny światowej (Kraków: Wyd. Literackie, 1987), 258. Warto dodać, że zamieszki te były reakcją na niekorzystne dla Polaków zapisy pokoju brzeskiego.

45 Plaschka, Haselsteiner i Suppan, Innere Front, cz. 2, Umsturz (München: R. Oldenbourg Verlag, 1974),, 106 i n.

46 Żołnierze pochodzenia polskiego stanowili ok. 8\% całego składu osobowego wojsk austro-węgierskich. Przyjmuje się, że w latach 1914-1918 przez szeregi tej armii mogło przejść do 700 tys. Polaków, zob. Michał Baczkowski, „Ilu Polaków walczyło w armii austro-węgierskiej podczas I wojny światowej?” w Mało znana Wielka Wojna. Studia i szkice z dziejów I wojny światowej, red. Aleksander Smoliński (Oświęcim: Napoleon V, 2014), 69-72. Warto 
na wykluczyć, że również żołnierze pochodzenia polskiego wykonujący obowiązki w armiach niemieckiej oraz rosyjskiej mieli świadomość możliwości wykorzystania ich do zadań z zakresu zapewnienia bezpieczeństwa publicznego, choć trzeba jasno tutaj zaznaczyć, że Polakom ze wszystkich trzech zaborów działalność taka mogła się kojarzyć wybitnie negatywnie. Niemniej w ostatnich latach I wojny światowej polscy żołnierze pełnili niekiedy zadania stricte policyjne, jak chociażby pododdziały I Korpusu Polskiego na terenach zrewolucjonizowanej Rosji. ${ }^{47}$ Także w procedowanych w połowie 1918 r. przez organy Rady Regencyjnej projektach aktów prawnych dotyczących administracji publicznej przewidywano ewentualność użycia sił wojskowych „w wypadkach wyjątkowych” na żądanie wojewody. ${ }^{48}$ Niewątpliwie do udziału Polaków w asystencji wojskowej dochodziło w ramach działań armii austro-węgierskiej pod koniec wojny, m.in. na obszarze dzisiejszej Bośni i Hercegowiny. ${ }^{49}$ Jeden z organizatorów oswobodzenia Krakowa w październiku 1918 r. - por. Antoni Stawarz - pełnił wówczas obowiązki w batalionie asystencyjnym, a z jego wspomnień wynika, że wraz z podległymi sobie żołnierzami wcześniej brał udział w specjalnym szkoleniu poświęconym tego rodzaju działaniom..$^{50}$

Obejmowanie władzy przez polską administrację nad kolejnymi obszarami kraju w listopadzie $1918 \mathrm{r}$. wiązało się z koniecznością angażowania posiadanych jednostek wojskowych do zapewnienia bezpieczeństwa publicznego. Znaczący wpływ na ten stan rzeczy miała wielość zagrożeń oraz słabość dopiero co organizowanych sił policyjnych. Przykładowo, 6

także zaznaczyć, że do tworzącego się w 1918 r. Wojska Polskiego przyjęto co najmniej kilkanaście tysięcy oficerów, pełniących poprzednio służbę w armii austro-węgierskiej. Marian Romeyko wylicza tę grupę na ok. 12-15 tys. i niezależnie od różnej oceny merytorycznej przedstawianych przez niego faktów to liczba ta może być zgodna z rzeczywistością, zob. Marian Romeyko, Przed i po maju (Warszawa: Wyd. Ministerstwa Obrony Narodowej, 1967, wyd. 3), 57-60 i 73. Lech Wyszczelski uważa, że oficerowie wywodzący się armii austro-węgierskiej byli najliczniejszą wśród oficerów grupą z tych, które tworzyły Wojsko Polskie, zob. Lech Wyszczelski, Wojsko II Rzeczypospolitej (Warszawa: Bellona, 2014), 23.

47 Wojciech Jerzy Muszyński, Białe Legiony 1914-1918. Od Legionu Puławskiego do I Korpusu Polskiego (Warszawa: Instytut Pamięci Narodowej, 2018), 288, 364.

48 Zdzisław Julian Winnicki, Rada Regencyjna Królestwa Polskiego i jej organy (1917-1918) (Wrocław: Wektory, 2017), 298.

49 Edmund von Glaise-Horstenau, Upadek Austro-Węgier, tłum. Katarzyna Mróz-Mazur (Oświęcim: Napoleon V, 2019), 260.

50 Zgórniak, 1914-1918, 264-271. Antoni Stawarz wspominał: „Wyjmuję gwizdek służbowy i wydaję jeden, długi, przeraźliwy gwizd. Na ten sygnał wypada ppor. Śnigowski z ludźmi, ukrytymi za barakiem i błyskawicznie wprost otacza zbrojnym kordonem przerażoną gromadę niemiecką. Nie na darmo uczono tej sztuki w celach asystencyjnych", zob. Antoni Stawarz, „Fragmenty pamiętnika,” stawarz.podgorze.pl, dostęp wrzesień 2, 2019, http://stawarz. podgorze.pl/pamietnik.html. 
listopada tr. użyto pododdziału złożonego z 40 żołnierzy do ujęcia bandy dezerterów napadającej na mieszkańców w okolicach Wadowic, 7 listopada zaangażowano kompanię piechoty do przywrócenia spokoju po rozruchach w Tarnowie, a 8 listopada kolejną kompanię do zabezpieczenia przebiegu demonstracji w Warszawie. ${ }^{51} 11$ listopada 1918 r. żołnierze garnizonu kieleckiego na żądanie prezydenta tego miasta podejmowali działania porządkowe wobec sprawców ekscesów antyżydowskich. ${ }^{52} \mathrm{Z}$ kolei 29 listopada tłum wdarł się do siedziby Rady Ministrów - Pałacu Namiestnikowskiego $\mathrm{w}$ Warszawie, co ponownie pokazało niedomagania $\mathrm{w}$ funkcjonowaniu cywilnych formacji porządkowych. W grudniu 1918 r. doszło do krwawych starć pomiędzy wojskiem a bojówkami robotniczymi w Zagłębiu Dąbrowskim, natomiast w okolicach Rzeszowa, Tarnobrzegu oraz Komańczy działały samozwańcze władze, nieuznające państwa polskiego. ${ }^{53}$ Przy ocenie położenia Polski nie można zapominać o ówczesnej sytuacji międzynarodowej w tej części Europy, w tym rozprzestrzenianiu się rewolucji bolszewickiej oraz wewnętrznych zaburzeniach w Niemczech.

Można założyć, że wobec wspomnianych niebezpieczeństw oraz przy świadomości faktycznego braku alternatyw kolejni premierzy oraz niektórzy przedstawiciele terenowej administracji publicznej zdawali sobie sprawę z konieczności wykorzystywania pododdziałów sił zbrojnych do zapewnienia bezpieczeństwa publicznego. Być może świadomość taką miał sam Józef Piłsudski, jeszcze w trakcie pobytu w Magdeburgu wspominający o potrzebie sformowania „armii, która wystarczyłaby w sprawach wewnętrznych”, jak również obserwujący na własne oczy efekty rewolucyjnego wzburzenia i chaosu w Niemczech. ${ }^{54}$ Zapewne najprostsze do wykorzystania w tej sytuacji wydały się wzorce austro-węgierskie, szczególnie, że przywracanie faktycznego władztwa polskiego rozpoczęło się od terenów będących w dotychczasowej gestii tego właśnie zaborcy. Już 4 listopada 1918 r. w ramach Polskiej Komendy Wojskowej w Krakowie zaczął funkcjonować referat asystencji, koordynujący ewentualne użycie sił wojskowych w obrębie miasta. ${ }^{55} 17$ listopada na obszarze administrowanym przez władze polskie

\footnotetext{
51 „Napady bandyckie na Zator, Krzeszowice i Alwernię," Ilustrowany Kuryer Codzienny, listopad 7, 1918, 3; „Zaburzenia w Tarnowie," Ilustrowany Kuryer Codzienny, listopad 8, 1918, 3; „Z za kulis «dyrektoriatu», Ilustrowany Kuryer Codzienny, listopad 9, 1918, 1.

52 Dominik Flisiak, „Pogrom ludności żydowskiej w Kielcach z 11-12 listopada 1918 roku. Przyczyny, przebieg, konsekwencje," Facta Simonidis 10, (2017): 249 i 252.

53 Jędrzej Moraczewski, Przewrót w Polsce, wstęp i oprac. Tomasz Nałęcz (Warszawa: Muzeum Historii Polski, 2015), 118; Chwalba, 1919. Pierwszy rok wolności (Wołowiec: Wyd. Czarne, 2019), 68-69, 109.

54 Jerzy Holzer, „Rozmowa Piłsudskiego z hrabią Kesslerem,” Kwartalnik Historyczny 68, nr 2 (1961): 447-450.
}

55 Wywiał, Garnizon, 51. 
przekształcono lokalne struktury wojskowe w pięć okręgów generalnych, a w ramach ich dowództw wyodrębniono sztaby, w których utworzono komórki organizacyjne zajmujące się sprawami udzielania asystencji wojskowej. ${ }^{56} 4$ grudnia 1918 r. w Dowództwie Okręgu Generalnego w Krakowie wydano $\mathrm{w}$ związku $\mathrm{z}$ tym polecenie tworzenia oddziałów asystencyjnych „złożonych z ludzi pewnych". ${ }^{77} \mathrm{Z}$ kolei 1 stycznia 1919 r. naczelnik Wydziału Administracji Polskiej Komisji Likwidacyjnej w Krakowie przypominał komisarzom terenowym o "niezmienionej dotąd dawnej instrukcyi o asystencyi wojskowej” i polecał, aby „w każdym wypadku użycia asystencyi wojska lub straży bezpieczeństwa, delegować na miejsce rozruchów [...] jednego z konceptowych urzędników starostwa, który w myśl obowiązujących [przepisów - przyp. P.H.] ma się w wypadkach takich zachować". Wydaje się, że powyższe zalecenie mogło mówić jedynie o wciąż wykorzystywanych normach pochodzenia austro-węgierskiego. ${ }^{58}$

Niewątpliwie czynnikiem, który miał wpływ na uwzględnianie wojska $\mathrm{w}$ zapewnianiu bezpieczeństwa publicznego $\mathrm{w}$ odradzającym się państwie, była słabość posiadanych w dyspozycji przez władze formacji o charakterze policyjnym. W listopadzie 1918 r. utrzymanie porządku w kraju spoczęło na szeregu powstałych oddolnie formacji - milicjach (straży) miejskich, gminnych i ludowych, które tworzono niezależnie od siebie, przydzielając im różne zadania. Wyposażenie oraz dobór pracujących w nich osób pozostawiały wiele do życzenia. Do tego na terenie Galicji funkcjonowała formalnie odrębna poaustriacka żandarmeria polowa, w której pozostała część funkcjonariuszy narodowości polskiej, a w niektórych częściach państwa obowiązki wykonywały straże: skarbowa i kolejowa. Bardziej znaczące frakcje polityczne także zaczęły tworzyć formacje uzbrojone: Polska Partia Socjalistyczna - Milicję Ludową, a Narodowa Demokracja - Straż Narodową. Podjęta już w grudniu tr. próba wykorzystania Milicji Ludowej w charakterze ogólnopaństwowym zakończyła się po paru miesiącach fiaskiem $\mathrm{z}$ uwagi na brak apolityczności wśród jej członków oraz bardzo niski poziom ich pracy. Z kolei o ówczesnych warunkach zapewniania bezpieczeństwa publicznego w Polsce może świadczyć fakt, że Straż Narodowa wzięła udział w prawicowym

56 Ibid., 64; Ostanek, „Dowództwo Okręgu Generalnego «Lwów», czyli o początkach terenowej administracji wojskowej w Małopolsce Wschodniej (1919-1921)," Historia i Świat 3 (2014): 186 i 191.

57 Wywiał, Garnizon, 66.

58 Archiwum Państwowe w Przemyślu, Polska Rada Narodowa w Przemyślu, sygn. 56/140/0/1/2, Pismo naczelnika Wydziału Administracji Polskiej Komisji Likwidacyjnej do komisarzy Polskiej Komisji Likwidacyjnej, l.dz. 1020/P.K.L.Adm., Kraków, 1 I 1919 r., skan 13, dostęp grudzień 20, 2020, http://www.skany.przemysl.ap.gov.pl/show.php?zesp=140\&cd $=0 \&$ ser $=1 \&$ syg $=2$. 
zamachu stanu w Warszawie w nocy z 4 na 5 stycznia 1919 r. i musiała zostać rozbrojona przez jednostki wojskowe. ${ }^{59}$

Zachodzącym zmianom $\mathrm{w}$ państwie towarzyszyło wprowadzanie stosownych regulacji prawnych. 2 stycznia 1919 r. Naczelnik Państwa Józef Piłsudski wydał dekret o używaniu wojska $\mathrm{w}$ wypadkach wyjątkowych. ${ }^{60}$ Przepis ten przewidywał możliwość wykorzystania w szczególnych przypadkach i na żądanie ministra spraw wewnętrznych lub podległych mu organów jednostek wojskowych dla zabezpieczenia porządku publicznego. Dekret zobowiązywał także ministrów spraw wojskowych oraz spraw wewnętrznych do wypracowania szczegółowych przepisów, określających sposób wykorzystania wojska do powyższych zadań. 30 stycznia tr. Rada Ministrów zatwierdziła w związku z tym Przepisy o użyciu wojska do pomocy władzom cywilnym. ${ }^{61}$ Ostatecznie 18 kwietnia 1919 r. wydano wspomniane już rozporządzenie o sposobie użycia wojska dla zabezpieczenia porządku publicznego. Ten akt normatywny w zakresie określenia przypadków wykorzystania sił zbrojnych kopiował sformułowania ze styczniowych przepisów, natomiast $\mathrm{w}$ obszarze ewentualnego stosowania broni przez żołnierzy ewidentnie wzorował się na regulacjach austro-węgierskich, w szczególności na projekcie instrukcji asystencyjnej z $1908 \mathrm{r}$. Także przyjęte $\mathrm{w}$ tym rozporządzeniu inne wymogi udzielania przez wojsko wsparcia dla władz cywilnych, m.in. dotyczące unikania użycia broni i niepotrzebnego rozlewu krwi, optymalnych rozwiązań taktycznych, ostrzegania dźwiękowego przed atakiem lub oddaniem salwy czy zakazu strzelania w powietrze, przypominają przepisy stosowane $\mathrm{w}$ armii byłego zaborcy. Wydanie omawianego aktu normatywnego zakończyło wstępny etap organizowania systemu asystencji wojskowej w siłach zbrojnych II Rzeczypospolitej.

\section{Podsumowanie}

Wykorzystanie wojska do wsparcia władz cywilnych w zapewnieniu odpowiedniego poziomu bezpieczeństwa wewnętrznego posiada długoletnią tradycję. Wynika to z cech i możliwości oddziałów zbrojnych, których organizacja i posiadana broń pozwalały traktować je jako środek przymusu

\footnotetext{
59 Fragment ten skrótowo opisuje realia tworzenia formacji policyjnych w okresie powstawania zrębów II RP. Oprócz wymienionych podmiotów można by wspomnieć jeszcze o Policji Komunalnej i Żandarmerii Krajowej, przy czym wszystkie one funkcjonowały obok Milicji Ludowej, co wobec braku dokładnie określonych wzajemnych relacji pomiędzy nimi powodowało poczucie chaosu. Istnieje wiele publikacji na temat początków formacji policyjnych w II RP, zob. Litwiński, „O bezpieczeństwo,” tam także literatura dotycząca tego wątku.

60 Dziennik Praw Państwa Polskiego z 1919, nr 1, poz. 80.

61 Wywiał, Garnizon, 75.
} 
w sytuacji zaburzeń społecznych bądź jako środek pomocy w przypadku klęski żywiołowej. Przedsięwzięcia takie na terenach polskich miały miejsce pod koniec istnienia I Rzeczypospolitej, a następne doświadczenia pochodziły od zaborców. W Austrii już od końca XVIII w. zaczęto używać zwrotu „asystencja wojskowa”, oznaczającego przeznaczenie żołnierzy do pomocy władzom publicznym w celu pokonania oporu podczas egzekwowania prawa. Rozwiązania prawne dotyczące tej problematyki pojawiły się w XIX w. $\mathrm{w}$ wielu państwach europejskich.

Z biegiem czasu kluczowa rola wojska stała się pomocnicza wobec działalności cywilnych formacji policyjnych, jednak z możliwości zastosowania sił zbrojnych nigdy nie zrezygnowano. W ciągu XIX oraz na początku XX w. wielokrotnie dochodziło do wykorzystania pododdziałów wojskowych do ochrony ustroju państwa, przywrócenia naruszonego zbiorowo porządku publicznego w związku ze strajkami robotniczymi bądź wystąpieniami chłopskimi. Znacznie rzadziej żołnierze pomagali poszkodowanym w sytuacjach wystąpienia katastrof naturalnych, jednak znane są również tego typu przypadki. W kontekście zaburzeń społecznych daje się zauważyć pewna powtarzalność w ich przebiegu i konieczność angażowania sił wojskowych do wsparcia formacji policyjnych w sytuacji eskalacji starć. Będące efektem I wojny światowej wypadki rewolucyjne, mające miejsce przede wszystkim w Rosji, lecz później także w monarchii austro-węgierskiej oraz w Niemczech, musiały mieć ogromny wpływ na postrzeganie zagrożeń bezpieczeństwa wewnętrznego przez ówczesnych decydentów. W szczególności niepokojące wrażenie mógł wywoływać obserwowany paraliż władzy publicznej i jej stopniowy rozkład. Doświadczenia te z pewnością oddziaływały również na wyobraźnię polskich polityków, dowódców wojskowych oraz społeczeństwa.

Odtwarzanie niepodległego państwa polskiego w ostatnich miesiącach 1918 r. odbywało się w niezmiernie ciężkich okolicznościach, zarówno jeżeli chodzi o sytuację zewnętrzną, jak i wewnętrzną w kraju. Praktycznie od początku obejmowania władzy nad poszczególnymi rejonami państwa administracja publiczna borykała się z poważnymi zagrożeniami bezpieczeństwa publicznego, tym trudniejszymi do opanowania, że nie istniały jeszcze wówczas profesjonalne siły policyjne. Wykorzystanie wojska do zapewnienia lub przywrócenia naruszonego porządku publicznego mogło w tych warunkach wydawać się koniecznością i to pomimo posiadania zapewne negatywnych skojarzeń z okresu zaborów w tym względzie. ${ }^{62}$ Świadomość możliwych do

\footnotetext{
62 Warto pamiętać, że w odtworzonym państwie polskim w zakresie zapewnienia bezpieczeństwa wewnętrznego korzystano także z innych rozwiązań pochodzących od zaborców - przykładowo w kontekście stanów nadzwyczajnych, zob. Piotr Krzysztof Marszałek, „Ślady obcych regulacji w polskim prawie stanów szczególnych," Studia Lubuskie 8, (2012): 13-30.
} 
wystąpienia niebezpieczeństw na tle społecznym, socjalnym czy ekonomicznym w odrodzonej Rzeczypospolitej, łącznie z ewentualnym oddziaływaniem ruchu bolszewickiego, musiała być na przełomie lat 1918/1919 u kluczowych polskich decydentów znaczna i zaangażowanie wszelkich legalnych środków do ochrony państwowości wydaje się uzasadnione.

Wprowadzeniu systemu asystencji wojskowej w Polsce sprzyjały przy tym gotowe i przemyślane rozwiązania prawne stosowane w tym obszarze przez siły zbrojne Austro-Węgier. Zawierały one w sobie podstawowe zasady oraz sposoby prowadzenia asystencji, a normy te zostały wykorzystane w czasie trwania I wojny światowej, ze szczególnym uwzględnieniem roku 1918. Niektórzy żołnierze narodowości polskiej służący w armii austro-węgierskiej mieli szansę zapoznać się z pojęciem asystencji wojskowej oraz regulacjami jej dotyczącymi, a pewna ich grupa odbyła szkolenia lub prowadziła bezpośrednie czynności tego typu (przykład por. Stawarza). Rozwiązania dotyczące użycia wojska do zapewnienia bezpieczeństwa publicznego wprowadzono na terenie Małopolski jeszcze przed umownym odzyskaniem niepodległości 11 listopada 1918 r. i bazowały one na dalej stosowanych regulacjach austro-węgierskich. W drugiej połowie listopada tego roku formalnie rozszerzono zakres udzielania wsparcia dla władz cywilnych na obszar całego kraju, poprzez utworzenie komórek organizacyjnych w administracji wojskowej odpowiedzialnych za koordynowanie tego typu przedsięwzięć. Trzeba także zaznaczyć, że jednym z elementów procesu budowania systemu asystencji wojskowej w II RP była słabość formacji policyjnych, tworzonych w oparciu o różne koncepcje i niepotrafiących w wystarczającym stopniu zapewnić bezpieczeństwa i porządku publicznego.

W okresie od stycznia do kwietnia 1919 r. wypracowano podstawy prawne udzielania asystencji wojskowej w II Rzeczypospolitej, a analiza ich treści pokazuje, że przynajmniej w części były wzorowane na przepisach austro-węgierskich - co zresztą z pewnych względów wydaje się racjonalne. Należy nadmienić, że powyższe spostrzeżenia powinny stanowić jedynie podłoże do dalszych badań naukowych, w szczególności dotyczących ewentualnego wpływu regulacji innych państw na polskie rozwiązania oraz zwiększenia zakresu tych unormowań o udzielanie pomocy podczas klęsk żywiołowych.

\section{Bibliografia}

Archiwalia

Archiwum Państwowe w Przemyślu

Polska Rada Narodowa w Przemyślu

Centralne Archiwum Wojskowe Wojskowego Biura Historycznego

Instrukcje i regulaminy przedwojenne 


\section{Akty prawne}

Dziennik Praw Państwa Polskiego z 1919 r.

\section{Opracowania}

Adamczyk, Elżbieta. „Władze samorządnego Krakowa wobec klęsk naturalnych nawiedzających miasto w dobie autonomii galicyjskiej." W Od powietrza, głodu, ognia i wojny... Klęski elementarne na przestrzeni wieków. Red. Tomasz Głowiński i Elżbieta Kościk, 171-186. Wrocław: Wyd. GAJT, 2013.

Baczkowski, Michał. „Ilu Polaków walczyło w armii austro-węgierskiej podczas I wojny światowej?." W Mało znana Wielka Wojna. Studia i szkice z dziejów I wojny światowej. Red. Aleksander Smoliński, 61-84. Oświęcim: Napoleon V, 2014.

Banaszek, Tadeusz. „Służba asystencyjna Wojska Polskiego w II Rzeczypospolitej przyczynki źródłowe." Świętokrzyskie Studia Archiwalno-Historyczne 5, (2016): 272-274.

Chwalba, Andrzej. 1919. Pierwszy rok wolności. Wołowiec: Wyd. Czarne, 2019.

Chwalba, Andrzej. Samobójstwo Europy. Wielka wojna 1914-1918. Kraków: Wyd. Literackie, 2014.

Cichoracki, Piotr i Janusz Mierzwa. „Akcja asystencyjna jednostek Wojska Polskiego w zachodniej części województwa lwowskiego (czerwiec-lipiec 1933 r.)." Przegląd Historyczno-Wojskowy 18 (69), nr 4 (262) (2017): 139-151.

Cichoracki, Piotr, Joanna Dufrat, Janusz Mierzwa i Piotr Ruciński, wstęp i oprac. Rzeczpospolita niedoskonała. Dokumenty do historii buntu społecznego w latach 1930-1935. Łomianki-Kraków: Wyd. LTW, 2019.

Farwell, Byron. The Encyclopedia of Nineteenth-Century Land Warfare: an illustrated world view. New York-London: W.W. Norton \& Company, 2001.

Flisiak, Dominik. „Pogrom ludności żydowskiej w Kielcach z 11-12 listopada 1918 roku. Przyczyny, przebieg, konsekwencje." Facta Simonidis 10, (2017): 243-260.

Franz, Maciej, Mariusz Kardas i Adam Adrian Ostanek. Wojsko Polskie a sytuacja wewnętrzna Małopolski Wschodniej. Działalność Rejonów bezpieczeństwa 5., 11. i 12. Dywizji Piechoty w latach 1924-1925. Warszawa: Stara Szuflada, 2018.

Gąsiorek, Krzysztof i Waldemar Kitler, red. i oprac. Wojskowe wsparcie władz cywilnych i społeczeństwa. Warszawa: Akademia Obrony Narodowej, 2005.

Glaise-Horstenau, Edmund, von. Upadek Austro-Węgier. Tłum. Katarzyna Mróz-Mazur. Oświęcim: Napoleon V, 2019.

Grześkowiak-Krwawicz, Anna, oprac. i wstep. Konstytucja 3 maja 1791 na podstawie tekstu ustawy rzadowej z archiwum Sejmu Czteroletniego przechowywanego w Archiwum Głównym Akt Dawnych w Warszawie. Warszawa: Archiwum Główne Akt Dawnych, 2018.

Hac, Piotr. „Asystencja wojskowa w II RP. Cz. I Przepisy regulujące i zasady udzielania." Kwartalnik Bellona, nr 3 (2017): 116-134.

Hac, Piotr. „Asystencja wojskowa w II Rzeczypospolitej. Cz. II Aspekty praktyczne.” Kwartalnik Bellona, nr 4 (2017): 52-70.

Holzer, Jerzy. „Rozmowa Piłsudskiego z hrabią Kesslerem.” Kwartalnik Historyczny 68, nr 2 (1961): 447-450.

Katechizm poddanych galicyjskich o prawach i powinnościach ich względem Rządu, Dworu i samych siebie przez Konstantego Leliwa Słotwińskiego. Lwów: b.w., 1832. 
Kowalczyński, Krzysztof R. Łódź 1905. Kulisy rewolucji. Łódź: Wyd. Księży Młyn, 2017. Kozłowski, Jan. „Straż ziemska w Królestwie Polskim w latach 1867-1875.” Przegląd Historyczny 91, nr 4 (2000): 519-534.

Laskowski, Otton, red. Encyklopedia wojskowa. T. 1. Warszawa: Wyd. Towarzystwa Wiedzy Wojskowej i Wojskowego Instytutu Naukowo-Wydawniczego, 1931.

Litwiński, Robert. „O bezpieczeństwo wewnętrzne odrodzonej Rzeczypospolitej (1917-1922)." Przegląd Historyczno-Wojskowy 19 (70), nr 1/2 (263/264) (2018): 218-244.

Majer, Piotr. Bezpieczeństwo wewnętrzne Polski w rozwoju dziejowym od X wieku do końca Polski Ludowej. Szczytno: Wyd. WSPol, 2012.

Marczuk, Karina Paulina. Trzecia opcja: gwardie narodowe w wybranych państwach basenu Morza Śródziemnego. Toruń-Łysomice: Europejskie Centrum Edukacyjne, 2009.

Marszałek, Piotr Krzysztof. „Ślady obcych regulacji w polskim prawie stanów szczególnych." Studia Lubuskie 8, (2012): 13-30.

Molenda, Jan. „Walka o poprawę warunków materialnego bytu robotników rolnych poprzez przemoc grupową i rokowania w rewolucji 1905-1907 roku w Królestwie Polskim." W Rewolucja 1905-1907 w Królestwie Polskim i w Rosji. Red. Marek Przeniosło i Stanisław Wiech, 59-82. Kielce: Wyd. Akademii Świętokrzyskiej, 2005.

Moraczewski, Jędrzej. Przewrót w Polsce. Wstęp i oprac. Tomasz Nałęcz. Warszawa: Muzeum Historii Polski, 2015.

Muszyński, Wojciech Jerzy. Białe Legiony 1914-1918. Od Legionu Puławskiego do I Korpusu Polskiego. Warszawa: Instytut Pamięci Narodowej, 2018.

Ochał, Artur. Na litewskiej rubieży. Brygada KOP „Grodno” (1929-1939). Warszawa: Instytut Pamięci Narodowej, 2017.

Ostanek, Adam Adrian. „Dowództwo Okręgu Generalnego «Lwów», czyli o początkach terenowej administracji wojskowej w Małopolsce Wschodniej (1919-1921)." Historia i Świat 3, (2014): 187-209.

Ostanek, Adam Adrian. Wydarzenia 1930 roku w Matopolsce Wschodniej a bezpieczeństwo II Rzeczypospolitej. Warszawa: Wyd. Adam Ostanek, 2017.

Plaschka, Richard Georg, Horst Haselsteiner i Arnold Suppan. Innere Front. Militärassistenz, Widerstand und Umsturz in der Donaumonarchie 1918. Cz. I, Zwischen streik und meuterei. Cz. II, Umsturz. München: R. Oldenbourg Verlag, 1974.

Prowincyonalny Zbiór Praw Galicyi i Lodomeryi za rok 1828, wydanego za naywyższym rozkazem pod dozorem c.k. galicyjskiego krajowego Gubernium. Lwów: b.w., [1829].

Romeyko, Marian. Przed i po maju. Wydanie 3. Warszawa: Wyd. Ministerstwa Obrony Narodowej, 1967.

Ryniewicz, Zygmunt. Bitwy świata: leksykon. Warszawa: Wiedza Powszechna, 1995.

Wierzbicki, Piotr. „Warszawski czerwony kur." Skarpa Warszawska, lipiec 2019, nr 7, 29-31.

Winnicki, Zdzisław Julian. Rada Regencyjna Królestwa Polskiego i jej organy (19171918). Wrocław: Wektory, 2017.

Wyszczelski, Lech. Wojsko II Rzeczypospolitej. Warszawa: Bellona, 2014.

Wywiał, Przemysław. Garnizon Wojska Polskiego w Krakowie w latach 1918-1939. Kraków: Wyd. Księgarnia Akademicka, 2019.

Zgórniak, Marian. 1914-1918. Studia i szkice $z$ dziejów I wojny światowej. Kraków: Wyd. Literackie, 1987. 


\section{Prasa codzienna}

Ilustrowany Kuryer Codzienny, listopad 1918.

\section{Internet}

„Newlyn Riots 1896.” west-penwith.org.uk. Dostęp sierpień 23, 2019. https://west-penwith.org.uk/riot.htm.

„The Riot Act.” gutenberg.org. Dostęp lipiec 23, 2019. http://www.gutenberg.org/files/ 8142/8142-h/8142-h.htm.

„The Peterloo Memorial Campaign.” Dostęp sierpień 22, 2019. http://www.peterloomassacre.org/history.html.

Stwarz, Antoni. „Fragmenty pamiętnika” stawarz.podgorze.pl. Dostęp wrzesień 2, 2019. http://stawarz.podgorze.pl/pamietnik.html. www.stawarz-podgorze.pl.

\section{STRESZCZENIE}

\section{Piotr Hac, Geneza asystencji wojskowej w II Rzeczypospolitej}

W artykule przedstawiono zagadnienie genezy asystencji wojskowej w II Rzeczypospolitej. Pod nazwą tą w międzywojennej Polsce rozumiano udzielanie pomocy przez siły zbrojne na rzecz władz cywilnych, przede wszystkim w związku z zapewnieniem bezpieczeństwa publicznego bądź w przypadku wystąpienia klęsk żywiołowych. W tekście poddano analizie doświadczenia polskie i zagraniczne z użycia wojska do wskazanych celów, jak również scharakteryzowano regulacje państw obcych powstałe przed 1918 r. w tym zakresie. Już w pierwszych dniach listopada 1918 r. na terenach Galicji administracja polska korzystała z pomocy sił wojskowych, przy czym wspomagano się dotychczas obowiązującymi normami austro-węgierskimi. W kolejnych miesiącach utworzono na terenie całego kraju komórki organizacyjne w administracji wojskowej zajmujące się koordynowaniem udzielania asystencji wojskowej, natomiast w okresie od stycznia do kwietnia 1919 r. wydano podstawowe przepisy dotyczące omawianej problematyki.

Słowa kluczowe: Siły zbrojne, asystencja wojskowa, geneza, II Rzeczypospolita, bezpieczeństwo publiczne

\section{SUMMARY}

\section{Piotr Hac, The Genesis of Military Assistance in the Second Republic of Poland}

This article presents the issue of the genesis of military assistance in the Second Republic of Poland. In interwar Poland, this was understood as aid that was to be provided by the armed forces in support of the civil authorities, primarily in connection with ensuring public safety, or in the event of natural disasters. The text analyzes both Polish and foreign experiences with the use of the army in this 
manner, as well as characterizing the regulations that were developed in this area in other countries before 1918. The Polish administration was already benefitting from military assistance in the territory of Galicia at the beginning of November 1918, with the support of the current Austro-Hungarian standards. In the following months, the military administration organized units throughout the country that would coordinate the provisioning of military assistance, and from January to April 1919 basic regulations concerning the matter were issued.

Keywords: Armed forces, military assistance, genesis, the Second Republic of Poland, public security

\section{АННОТАЦИЯ}

\section{Пётр Хац, Генезис военной помощи во Второй Речи Посполитой}

В статье рассматривается вопрос генезиса военной помощи во Второй Речи Посполитой. В межвоенной Польше это выражение понималось как оказание помощи вооруженными силами гражданским властям - в первую очередь, в связи с обеспечением общественной безопасности или в случае стихийных бедствий. В тексте статьи анализируется польский и зарубежный опыт использования армии для указанных целей, а также дается характеристика постановлений зарубежных стран, которые были приняты до 1918 г. в этом отношении.

Уже в первые дни ноября 1918 г. на территории Галиции польская администрация пользовалась помощью вооруженных сил, при этом на тот момент все еще действовали австро-венгерские стандарты. В последующие месяцы по всей стране были созданы организационные подразделения военной администрации для координации оказания военной помощи, а в период с января по апрель 1919 г. были изданы основные положения, касающиеся исследуемой проблематики.

Ключевые слова: Вооруженные силы, военная помощь, генезис, Вторая Речь Посполитая, общественная безопасность 